\title{
ВЫСОЦКИЙ МАЛЕНЬЧУКА. СКОЛЬКО МАЛЕНЬЧУКА В ПЕРЕВОДАХ ПЕСЕН ВЫСОЦКОГО?
}

\author{
Maleńczuk's Vysotsky. How much of Maleńczuk is in Translations \\ of Vysotsky's Songs?
}

Keywords: translation, maleńczuk, vystotsky, bards, song, poetry, author song, shanson Contact: Uniwersytet Ślaski w Katowicach; szymonbryzek@gmail.com

Подлинный текст, переводчик и перевод являются неизменяемыми и неотъемлемыми составляющими процесса перевода, который можно метафорически описать как путь текста (в случае наших исследований художественного), созданного автором, к читателю или слушателю, которые не пользуются языком оригинала (Lewicki 2017: 67).

Лингвистические дисциплины, занимающиеся исследованием художественных текстов, сосредоточиваются, как правило, на языковых факторах, местах в литературных полисистемах разных культур, а также на переводе, его цели и способах достижения эквивалентности. Лишь в небольшой степени они уделяют внимание автору, а еще в меньшей - переводчику и читателю, а ведь отношения между ними - это также существенный фактор процесса перевода.

В схеме интерпретативной теории коммуникации Оттона Каде, переводчик должен выполнять две роли: получателя исходного текста (interpreter / listener) и создателя текста перевода (interprgeter / speaker). Для соответствующей и качественной передачи смысла исходного текста, переводчик должен его понимать и интерпретировать (Lewicki 2017: 68).

Согласно классическим парадигмам перевода, переводчик пытается остаться «прозрачным», направляя внимание читателя на автора и его мысль. Анна Легежинска, в своей работе посвященной переводчику и его авторской компетенции, обращает внимание на тот факт, что читатель, скорее всего, запомнит автора текста чем фамилию переводчика (Legeżyńska 1999: 22). 
Однако, наряду с развитием гуманитарных наук, занимающихся взаимоотношениями литературы, языка и культуры, а также возникновением новых парадигм в области переводоведения (translation studies, теории скопоса и деконструктивизма), переводчик, его личность и цель (или скопос) стали объектом исследования, таким же значимым как оригинал и перевод.

В данной статье рассматриваются новейшие польские переводы песен Владимира Высоцкого, выполненные польским музыкантом и поэтом - Мачеем Маленьчуком. В центре нашего интереса находится, главным образом, влияние творческой личности переводчика на рецепцию текста перевода в другом культурном пространстве.

В начале наших рассуждений следует заметить, что переводы Маленьчука не являются первой попыткой трансфера текстов русского барда на почву польской культуры. Песни и личность Владимира Высоцкого оказали сильное влияние на советское культурное пространство 60-ых и 70-ых годов, но не только. Благодаря трудам многих польских переводчиков, Высоцкий и его тексты вошли также прочно в сознание массового польского слушателя и, заодно, в польскую литературную полисистему. Анна Беднарчик, польская ученая, занимающаяся исследованиями переводов песен Высоцкого, замечает, что польские слушатели изначально знакомились с творчеством русского барда в оригинале, часто не понимая содержания текстов. Тем не менее, именно потому, что это были песни, т. е. благодаря присутствии музыкального фактора, они могли их воспринимать, хотя естественно не без определенных потерь, в том числе семантических. (Bednarczyk 1995: 30).

На основании вышеизложенного можно сделать вывод о том, что музыкальный слой текста (инструментарий, ритмомелические, просодия русской речи, вокальное исполнение) в какой-то степени позволяют декодировать и воспринимать текст, если не полностью, то, по крайней мере, его общий смысл. Особо значимыми в данном контексте оказываются эмоции, заключенные в музыкальном слое текста и его исполнении.

Переводы Войчеха Млынарского, Михала Ягелло, Земовита Федецкого и Яцека Качмарского, а также других, которые не добились такой популярности как вышеперечисленные, были первыми, которые знакомили польского слушателя и читателя с Высоцким и его текстами. Они были выполнены мастерами своего дела, так что предоставляли возможность декодировать не только первоначальный смысл текста, но также ощущать эмоции, свойственные оригиналу. 
Переводы вышеупомянутых переводчиков, их специфика и уровень адекватности по отношению к подлинному тексту, были уже предметом многочисленных лингвистических исследований, тем не менее эта тема в дальнейшем кажется нам очень перспективной. А. Беднарчик в своей монографии Wysocki po polsku - problematyka przekładu poezji śpiewanej («Высоцкий по-польски - проблематика перевода авторской песни), посвященной переводам песен Владимира Высоцкого, обращает внимание на разные тенденции, наблюдаемые в польских переводах. А. Беднарчик относит к ним, в частности: замену русских слов-реалий польскими, что не всегда уместно (при этом теряется колорит текста), политизацию текстов (Качмарский), коллоквиализацию текстов (Федецкий) и адаптация текстов к сценической постановке (Млынарский) (Bednarczyk 1995: 9).

Внимание ученой сосредоточено на переводческой рефракции в текстах польских переводчиков, а также на лингвистических и внелингвистических факторах. Имеем здесь в виду, прежде всего, общественно-политическую обстановку, предназначение с учетом формы исполнения, т. е. сценической постановки. А. Беднарчик обращает внимание на автора перевода и цель, которую он перед собой поставил. В качестве примера она приводит знаменитого музыканта, автора текстов, сатирика и поэта Войчеха Млынарского. В Млынарски исполнял свои переводы не только в качестве записи песен, но и в сценической постановке, что находило отражение в его переводах (Bednarczyk 2002: 130).

Маленьчук, которого его польские фанаты называют «бардом Кракова» играет на улицах Кракова с 1982 года, т. е. после выхода из тюрьмы, куда он попал из-за отказа от военной службы (Sawala 1997:135). Его сценический дебют с группой «Дупа» имел место в 1985 году, потом сотрудничал с группой «Пуделси» и «Гомо Твист» (Sawala 1997: 136).

Деятельность Маленьчука не была до сих пор предметом научных исследований, хотя, как нам кажется, он сам и его творчество представляют собой очень интересный материал для анализа. Как показывают наши исследования, можно выделить несколько черт, характерных для его творческого языка. Они находят отражение также в переводах, выполненных Маленчуком. Итак, причисляем к ним:

1. употребление матерной лексики;

2. использование тюремного жаргона и лексики подстандарта (биографический фактор);

3. наличие русизмов или фраз на русском языке; 
4. интертекстуальные ссылки, которых нет в оригинальном произведении.

Перечисленный выше список характерных черт не является, конечно, комплексным. Мы обратили внимание лишь на те, которые являются важными с точки зрения перевода интересующих нас здесь песен. Переводы, выполненные Маленьчуком, это одиннадцать песен, которые вошли в альбом «Высоцкий Маленьчука» (ориг. Wysocki Maleńczuka). Интересным является уже само название альбома, так как оно ясно выражает отношение переводчика к автору. Маленьчук нередко прибезает к «захвату» текстов Высоцкого, пропуская их через фильтр собственных творческих методов и своих любимых языковых средств. То же самое происходит с музыкальным слоем текстов. Все записи представлены далеко не в стиле акустическо-гитарной аранжировки авторской песни.

Во введении к альбому Маленьчук пишет, что «ингеренции в аранжировке, которые мы совершили, могут испугать поклонников (Высоцкого). Однако - нас нельзя было остановить» ${ }^{1}$ (перевод Ш. Б.).

Приведенная выше цитата может быть воспринята в качестве «переводческого манифеста» Маленьчука, который сильно «вмешивается» не только в музыкальную аранжировку, но и в лингвистический уровень текста, отрицая парадигму «прозрачного» переводчика. Тексты Высоцкого подвергаются переводческому «переписыванию» (rewriting), рефракции, в которой внимание обращается на переводчика, его личность, цели и способ их достижения.

В дальнейшей части данной статьи мы обратим внимание на, интересные с точки зрения анализа перевода, изменения введены Маленьчуком.

В первую очередь мы обратим внимание на использование в переводах Маленьчука матерных выражений, которые в оригинальном произведении отсутствуют.

В качестве материала для анализа мы использовали песню «Czerwone zielone» (Красное зеленое), которая открывает альбом. В польском переводе наблюдаем много ненормативной лексики, которой не обнаруживаем в оригинале:

Ilé ja na ciebie, На тебя, отраву, деньги

kasy wypuścitem, словно с неба сыпались -

\footnotetext{
${ }^{1}$ Ingerencje muzyczne, jakich dokonaliśmy, mogą przerazić wyznawców. Jednak nic nie było w stanie nas zatrzymać.
} 
Franki i dolary, same grube nominaty, Крупными купюрами, займом W końcu się na taka,

mine wpierdolitem, золотым, -

ze pajde dostatem, takie czasy nastały złe czasy nastaly.

Но однажды всыпались, и сколько мын ни рыпались, Всё прошло, исчезло, словно с яблонь бельй дым.

Więc pies z toba tańcowat,

Komu chcesz przysięgaj,

А бог с тобой, с проклятою,

Dnia na mnie nie czekaj, komu trzeba taś się,

с твоею верной клятвою

О том, что будешь ждать меня ты

Twojej dupie prega,

dla mnie gruba księga, долгие года, -

Bóg nam nie wybaczy $i$ żegnaj na zawsze А ну тебя, патлатую, тебя саму и мать твою! $-$ Живи себе, как хочешь - я уехал żegnaj na zawsze. навсегда!

Аналогичное явление обнаруживаем в переводе припева Песенки о сентиментальном боксере:

Leżal i dumat, że żyźni harasza, $\quad$ Лежал он и думал: что жизнь Komu harasza, a komu ni chuja, хороша... Кому-хороша, а кому - ни шиша.

Как было уже сказано, в оригинале матерные выражения не выступают. Таким образом, их появление в переводе может вызывать разные реакции. Если слушатель более подготовлен и он ищет именно польский перевод песни Высоцкого, который сохраняет первоначальные смыслы и поэтику русского барда, то может быть сильно разочарован. В результате он может сделать вывод о том, что данные перевод не совпадает с оригиналом по многим критериям. Введение мата, там, где в оригинале его нет, тоже не всем может нравиться. Подругому будут воспринимать текст те, кто ознакомлен с творчеством самого Маленьчука. 
Как мы упоминали раньше, польский музыкант вводит в свои переводы тюремную лексику и коллоквиализмы, которые не встречаются в подлинном тексте.

Первый пример почерпнут из перевода песни Красное зеленое:

Ileż ja na ciebie,

kasy wypuściłem,

Franki i dolary, same grube nominaty, w końcu się na taka,

mine wpierdolitem,

je pajde dostałem, takie czasy nastatyzłe czasy nastaty.
На тебя, отраву, деньги

словно с неба сыпались -

Крупньли купюрами, займом

золотылм, -

Но однажды всыпались, и сколько мын ни рыпались, Всё прошло, исчезло, словно с яблонь бельй дымм.

Ниже мы приводим фрагмент перевода текста Баллада о гипсе:

Nic ci na głowę nie spadło - no trudno, Эx, жаль, что не роняли вам на череп

Żal mi was ludzie a ja to przeżytem,

Czy to nie fajnie mieć wstrząs mózgu,

To nawet lepsze niż strzat w żyle. утюгов, -

Скорблю о вас - как мало вы успели! Ах, это просто прелесть сотрясение мозгов,

Ах, это наслажденье - гипс на теле!

В авторских текстах польского музыканта, коллоквиализмы и тюремная лексика являются стандартными средствами выражения. И в песнях Маленьчука, и в его переводах, их наличие связано с биографическим фактором, который, как видно, оказывает сильное влияние на поэтический идиолект автора.

Следующих два примера, мы почерпнули из перевода текста Песенка сентиментального боксера. Они являются примером интересного явления, в котором устойчивые фразы русского языка появляются в переводе в адаптированной форме.

Описываемая нами тенденция видна в переводе второго куплета: 
Styszę siedem, jeszcze leżę, osiem zbieram sie,

Znów prostuję, znów nurkuję, oczka ida mnie,
При счете «семь»я все лежу, рыдают землячки.

Встаю, ныряю, ухожу, и мне идут очки.

Третьего куплета:

W trybunach gwizd, w trybunach śmiech, $\quad$ B трибунах свист, в трибунах вой: A ty jego to tchórz, Amу его, он трус! -

Приведенные нами примеры заслуживают анализа, так как они вызывают вопросы относительно лингвистических и переводческих способностей Маленьчука. Прием сохранить в переводе русские устойчивые словосочетания (кому-то идут очки и ату его) в качестве проявлений категории чужого, т. е. здесь без подобранного польского эквивалента, влияет несомненно на восприятие текста. Как нам кажется, трудно здесь оправдать такое переводческое решение. Оно не только осложняет восприятие текста, но может также свидетельствовать о том, что переводчик не до конца понимает значение данных фраз.

И в переводах, выполненных Маленьчуком, и в его оригинальном творчестве находим много русизмов. В качестве примера можно привести песню Pan Maleńczuk (Potem poszło już raz dwa-niebieski duży fiat // Depozyt cztery osiem kolegium - tiepier ja // Wina i kara - problem od lat // Rozwiazany w minute - miatem szczęście i tak) или в песни Ach, proszę pani (Ulica śpiewa hymn o dolarze // A wolni grażdanie szczerza szczerby). Русизмы являются здесь, как нам кажется, устойчивым средствами поэтического выражения, которое оставляет свой отпечаток в переводах.

Первый пример в почерпнут из перевода текста Красное зеленое:

Bladź nienasycone,

Ścierwo nienażarte,

Wszystkiego ci mało daczy nie wystarczy,
Бабу ненасытную, стерву неприкрытую

Сколько раз я спрашивал: «Хватит ли, мой свет?» 
Два следующих примера почерпнуты из перевода текста Москва-Oдесса.

Tam rośnie czaj lecz mnie on się nie Там чай растет, но мне туда не надо. nada

Последним примером, который показался нам интересным, является куплет Баллады о нейтральной полосе, в котором Маленьчук решает сохранить русскую фразу полностью.

A na neitralnoj polosie cwiety nieobyczajnoj krasaty
А на нейтральной полосе цветы необычайной красоть

Русизмы или выражения на русском языке встречаем, практически, во всех переводах Маленьчука. Этот прием в какой-то степени «оставляет» текст в его исходном лингвокультурном пространстве и является информацией для польского слушателя о том, что данная песня, происходит из другой культуры, которую легко декодировать.

Подытоживая наши размышления, мы хотим еще остановиться на интертекстуальных ссылках, которые используем Маленьчук. Они, как правило, относятся к польской музыке и культуре.

Проиллюстрируем это фрагментом перевода песни Тот, кто раньще с нею был:

A miatem nóż, więc myślę cóż,

Nie dam się wziąć jak jakiś tchórz,

Ten nóż nie będzie już do chleba,
Со мною нож, решил я: что ж,

Меня так просто не возьлёшь.

Держитесь, гадь!! Держитесь, гадь!!

Ссылаясь в своих переводах на тексты представителей классики польского блюза и рока, Маленьчук вступает со слушателем в своеобразную языковую игру. Тот, кто хорошо ориентируется в вопросах польской музыки, сразу обнаружит здесь ссылку на польскую блюз-роковую группу Breakout, основанную Тадеушом 
Налепой. В песни Oni zaraz przyjda tu Налепа поет, употребляя фразу, которая прочно закрепилась в сознании поляков: Na pewno masz mi za złe // Że ten właśnie wziałem nóż // Na pewno masz mi za złe Oni zaraz przyjda tu // Wiem nóż ten byl do chleba // Oni zaraz wezma mnie.

Появление данной ссылки можно объяснить сходством сюжета и композиции текстов Высоцкого и Налепы - герои обоих песен находятся в опасности и они вынуждены защищаться.

Однако, следует заметить, что в оригинале не наблюдаем никаких ссылок. Таким образом, данный прием следует считать очередным проявлением вмешательства переводчика в оригинальное произведение и, одновременно, попыткой оставить свой авторский отпечаток.

Второй пример почерпнут из перевода песни Певец у микрофона:

Dwa reflektory pala mnie pod żebra, Бьют лучи от рампь мне под рёбра,

Lecz będe grat $w$ teatrze, jakże nie grać, $\quad$ светят фонари в лищо недобро,

Niczym w martenie dziś na scenie skwar, и слепят с боков прожектора,

$\dot{Z} a r, \dot{z} a r, \dot{z} a r$.

$$
\text { u-жара! жара! жара! }
$$

В польском переводе, как видим, появляется слово marten, которое обозначает мартеновскую печь. Можно это трактовать как ссылку на ставшую уже культовой песню Autobiografia польской рок-группы Perfect

Подытоживая сказанное, можно прийти к выводу, что все обнаруженные и описываемые нами переводческие трансформации и другие решения, можно объяснить, прежде всего, особыми чертами переводчика. Маленьчук в своих переводах пытается передать смыслы и значения оригинала, однако передает их с помощью своего поэтического идиолекта, а не признанных эквивалентов, не с помощью точных эквивалентов. Его переводы можно воспринимать, скорее всего, как адаптации, в которых находит отражение творческая личность переводчика.

Маленьчук, иначе чем Гоголь, не хочет быть переводчиком прозрачным как стекло. Наоборот - он стремится оставить сильный отпечаток своего творчества и личности. Его переводческая позиция сходна в этом плане с позициями, которые уже существуют в современном переводоведении. Это явление хорошо 
подытоживает Николай Константинович Гарбовский: «Переводчик же не есть «прозрачное стекло». При всей любви и уважении к автору, относясь со всей скрупулезностью к мельчайшим деталям смысловой и формальной организации оригинала, переводчик создает новый предмет на основе собственных представлений о мире, частью которого является и переводимый им текст» (Гарбовский 2008: 36).

\section{Summary}

The aim of the article was to analyze the influence of the author (his personality, biographical factor and poetic idiolet) on the translated texts. In my research I used translations of texts by Włodzimierz Wysocki, written by Polish musician - Maciej Maleńczuk. The changes introduced by the translator were analysed, an attempt was made to explain their motivation and their influence on the reception of translated text.

\section{Literatura}

Гарбовский, Н. К. Отражение как свойство перевода. Вестник Московского университета, Сер. 22. Теория перевода. 2008 (4), с. 26-36.

Bednarczyk, A. Wysocki po polsku. Łódź: Wydawnictwo UŁ, 1995.

Bednarczyk, A. Kto thumaczy - jak thumaczy. In: Fast, P., Kozak, A. (eds.) Biograficzne konteksty przekładu. Katowice: Śląsk, 2002, s. 127-138.

Legeżyńska, A. Ttumacz i jego kompetencje autorskie. Warszawa: PWN, 1999.

Lewicki, R. Zagadnienia lingwistyki przekładu. Lublin: Wydawnictwo Uniwersytetu Marii Skłodowskiej-Curie, 2017.

Sawala, K. Maciej Maleńczuk. In: Jakubowski, M., Szalbierz, M. (eds.) Encyklopedia Muzyki Popularnej - Blues w Polsce. Poznań: Atena, 1997, s. 135-136. 